\title{
Usulan Pembaharuan jadwal Kegiatan Preventive Maintenance pada Mesin Curing PCR PT.XYZ Menggunakan Metoda Distribusi Weibull
}

\author{
Herman Budi Harja, Nunu Ahmad Nugraha \\ Politeknik Manufaktur Negeri Bandung \\ Email: herman@polman-bandung.ac.id
}

\begin{tabular}{l}
\hline $\begin{array}{l}\text { Informasi } \\
\text { Artikel: }\end{array}$ \\
\hline Received : \\
2 Januari 2019 \\
Accepted: \\
4 Maret 2019 \\
Available \\
1 Desember \\
2019
\end{tabular}

\begin{tabular}{l}
\hline Kata Kunci: \\
\hline Perawatan tidak \\
terencana; \\
Expected \\
lifetime; \\
Pembaharuan \\
jadwal PM
\end{tabular}

\section{ABSTRAK}

Seringnya terjadi kegiatan perawatan (downtime) tidak terencana mesin Curing pada line produksi ban mobil PT XYZ merupakan indikasi adanya ketidakefektifan perawatan terencana (PM) yang diterapkan perusahaan. Downtime tidak terencana menyebabkan line produksi berhenti dan kehilangan waktu berproduksi, meningkatnya jumlah produk gagal saat setup, dan tingginya biaya perawatan mesin produksi. Perusahaan perlu meningkatan efektivitas dan efisiensi kinerja system perawatan melalui pembaharuan jadwal perawatan agar availability mesin tinggi. Tujuan penelitian ini adalah mengidentifikasi komponen penyebab kegagalan fungsi mesin curing dan menghasilkan rekomendasi waktu interval perawatannya yang sesuai. Metoda distribusi Weibull digunakan untuk mendapatkan nilai index of fit time to failure beberapa komponen kritis mesin, menganalisa laju kerusakan komponen, menghitung nilai mean time between failure (MTBF) komponen sebagai durasi expected lifetime komponen tersebut. Hasil yang diperoleh menunjukkan bahwa terdapat dua komponen kritis pada mesin curing dengan indikasi laju kerusakan seiring waktu (nilai $\beta>1$ ), yaitu silinder press dan EPV dengan nilai MTBF sebesar 89 hari untuk silinder press dan 231 hari untuk EPV. Hasil kajian ini mengusulkan pembaharuan jadwal PM mesin curing agar mempertimbangkan penambahan kegiatan PM baru yang mengakomodir nilai durasi expected lifetime dari komponen-komponen penyebab mesin breakdown, sehingga dapat meminimalkan downtime tidak terencana.

\begin{abstract}
The frequent occurrence of unplanned maintenance of curing machine on PT XYZ car tire production line is an indication of ineffectiveness implementation of the preventive maintenance. Unplanned downtime caused increasing of lost production time and failure products during setup, and also high cost maintenance. The company must improve the effectiveness and efficiency of the maintenance system performance through updating the maintenance schedule for obtaining high availability of the machine. The purpose of this study is to identify the components which cause the failure of the curing machine and give the recommendation of the appropriate maintenance interval. Weibull distribution method is used to get the index value of fit time to failure of machine components, analyze the component failure rate, calculate the mean time between failure (MTBF) as the expected lifetime of the component. The obtained result showed that there were two critical components with an indication of the increasing failure rate, as during wear-out ( $\beta$ value $>1$ ), which are namely cylinder press and EPV with an MTBF value of 89 days for cylinder presses and 231 days for EPV. The results of this study propose for updating the curing machine PM schedule. the adding pressure valve and EPV on PM activities and using the its expected lifetime as its PM interval should be considering. it will minimize unplanned downtime.
\end{abstract}




\section{Pendahuluan}

Mesin curing merupakan salah satu mesin produksi pada line produksi pembuatan ban di PT XYZ. Proses curing merupakan proses vulkanisasi ban yang berlangsung di dalam ruang chamber dengan temperature dan tekanan yang terkendali untuk mendapatkan sifat produk ban sesuai spesifikasi. Proses ini merupakan proses finishing dan berada di akhir line produksi ban. Jika terjadi mesin curing breakdown, maka akan menyebabkan proses produksi pada line produksi tersebut berhenti berproduksi. Saat ini kegagalan fungsi pada mesin curing (breakdown) sering terjadi walaupun telah dilakukan perawatan mesin dengan metoda preventive maintenance (PM). Metoda perawatan PM merupakan policy perawatan yang secara umum diterima dan digunakan perusahaan sebagai upaya perawatan yang terencana/ terjadwal berbasis waktu operasi penggunaan mesin $[1,2]$.

Interval atau selang kegiatan antar kegiatan PM dan lingkup daftar aktivitas setiap kegiatan PM adalah berdasarkan rekomendasi pabrik pembuat mesin maupun preventive maintenance berbasis nilai kerumitan pada mesin produksi. Nilai kerumitan mesin dihitung berdasarkan spesifikasi mesin dan asumsi kondisi operasi penggunaan mesin seperti[3]. Jika terjadi kegagalan fungsi Mesin curing di luar jadwal PM, maka hal ini mengakibatkan adanya kebutuhan kegiatan perawatan tidak terencana dan berdampak pada berkurangnya availability mesin, meningkatnya biaya perawatan mesin dan tingginya lost production, serta berujung pada kerugian perusahaan karena adanya keterlambatan delivery produk dan banyaknya produk gagal saat setup proses.

Availability adalah proporsi dari waktu mesin yang sebenarnya tersedia untuk melakukan produksi dengan waktu produksi yang ditargetkan seharusnya tersedia. availability adalah nilai ratio yang menunjukkan line stop ditinjau dari aspek downtime mesin. availability (A) adalah:

$A=\frac{\text { Total Operation Time }}{\text { Loading Time }} \times 100$

Kehandalan peralatan produksi akan berkurang seiring waktu operasi penggunaan dalam kondisi beban operasi ideal atau sesuai rekomendasi. Peralatan produksi akan mengalami penurunan kehandalan secara cepat jika dioperasikan pada kondisi beban operasi di atas kondisi rekomendasi pabrik pembuat mesin [4]. Perawatan merupakan upaya untuk perbaikan kehandalan peralatan agar kehandalannya selalu berada pada nilai optimum. Sering munculnya mesin breakdown ialah indicator bahwa jadwal perawatan PM mesin curing saat ini kurang efektif dan tidak sesuai dengan kondisi perkembangan kehandalan mesin dan kondisi operasi produksinya. Oleh karena itu diperlukan pembaharuan terhadap jadwal PM mesin termasuk pembaharuan lingkup item kegiatan PM_nya.

Mean Time Between Failure (MTBF) adalah rata - rata waktu suatu mesin dapat dioperasikan sebelum terjadinya kerusakan. MTBF ini dirumuskan sebagai hasil bagi dari total waktu pengoperasian mesin dibagi dengan jumlah/frekuensi kegagalan pengoperasian mesin karena breakdown. Hasil perhitungannya dapat dilihat pada di bawah ini:

$M T B F=\frac{\text { Total Operation Time }}{\text { Time Frekuensi Breakdown }}$

Maintainability adalah suatu usaha dan biaya untuk melakukan perawatan (pemeliharaan). Suatu pengukuran dari maintainability adalah Mean Time to Repair (MTTR), tingginya MTTR 
mengindikasikan rendahnya maintainability. Dimana MTTR merupakan indikator kemampuan (skill) dari operator maintenance mesin dalam menangani atau mengatasi setiap masalah kerusakan.

$M T T R=\frac{\text { total Breakdown Time }}{\text { Frekuensi Breakdown }}$

Beberapa penelitian pada topik penentuan interval perawatan PM telah dilakukan sebelumnya. Charles (2003) menyatakan bahwa PM merupakan upaya untuk mempertahankan kehandalan mesin melalu pelaksanaan perawatan yang periodic dalam fix interval waktu tertentu, tetapi belum dikaitkan dengan munculnya kegagalan fungsi mesin [5]. Oleh karena itu penelitian PM berlanjut pada berbagai modifikasi dan strategi interval PM. Imam Sodikin(2008) menggunakan pendekatan model Jardine untuk menentukan interval PM pada komponen mesin Excavator [6]. Destina Surya (2011) melakukan kajian usulan PM pada mesin cetak kertas menggunakan metoda RCM Reliability Center Maintenance untuk menentukan komponen kritis mesin berdasarkan analisa resiko yang terjadi jika terdapat kegagalan fungsi komponen [7].

Pada penelitian ini dilakukan kajian pembaharuan jadwal PM mesin curing melalui penelusuran dan perhitungan index of fit time TTR (Time to Repair) komponen kritis atau komponen yang menyebabkan mesin curing sering breakdown. Kajian ini menggunakan Metoda distribusi Weibull untuk mendapatkan nilai index of fit time to failure komponen kritis mesin. Nilai mean time between failure (MTBF) komponen sebagai durasi expected lifetime komponen tersebut. Nilai expected time diusulkan menjadi selang waktu atau interval antar kegiatan perawatan mesin curing. Pembaharuan jadwal PM mesin curing ini akan meminimalkan adanya kegiatan perawatan yang tidak terencana, sehingga system perawatan PM yang diterapkan perusahaan menjadi efektif dan efisien serta akan mempermudah sinkronisasi dengan jadwal produksi.

\section{METODOLOGI PENELITIAN}

Beberapa tahapan yang dilakukan pada penelitian ini dapat dilihat pada gambar 1 . Penelitian diawali dengan menelusuri data riwayat perawatan mesin curing selama durasi tertentu, kemudian menghitung dan memilah komponen mesin dengan karakter yang memerlukan perlakukan teknik perawatan PM, menghitung index of fit TTF dan survivability komponen yang menyebabkan mesin breakdown, dan berikutnya merekomendasikan usulan pembaharuan jadwal PM.

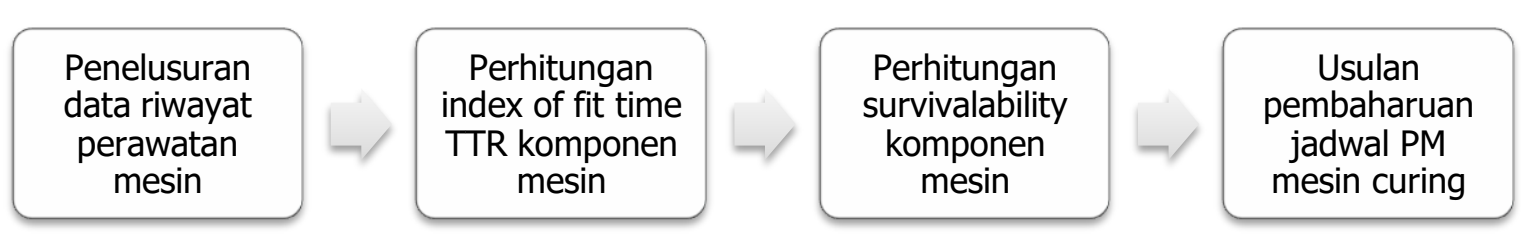

Gambar 1. Tahapan penelitian 


\subsection{Penelusuran data history perawatan mesin curing}

Penelusuran data histori diulakukan untuk mengamati riwayat pelaksanaan kegiatan perawatan mesin yang terjadwal PM dan yang tidak terjadwal (breakdown maintenance). Kemunculan kegiatan perawatan yang tidak terjadwal biasanya disebabkan adanya kegagalan komponen mesin sehingga mengganggu bahkan menyebabkan kegagalan fungsi mesin curing. Komponen-komponen mesin penyebab terjadinya breakdown maintenance tersebut disebut sebagai komponen kritis mesin. Breakdown maintenance dapat terjadi disebabkan oleh kegagalan fungsi satu komponen ataupun beberapa komponen mesin secara bersamaan.

Pengamatan data kerusakan komponen kritis mesin curing diambil selama 2 tahun 3 bulan yaitu dari bulan Januari 2016 sampai Maret 2019.

\subsection{Penentuan Index of fit time to failure (TTF) komponen kritis mesin curing.}

Komponen kritis merupakan komponen mesin yang menyebabkan mesin breakdown dan adanya kegiatan perawatan di luar jadwal PM. Berdasarkan penelusuran data histori terdapat dua komponen kritis pada mesin curing yaitu silinder press dan Electronic Propotional Valve (EPV). EVP merupakan komponen katup yang berfungsi untuk mengatur besaran debit aliran fluida N2 yang berpengaruh terhadap temperatur dan tekanan ruang chamber proses curing ban. EPV dituntut berfungsi secara real time dan memberi respon pengaturan aliran debit secara cepat sehingga sesuai dengan perubahan kebutuhan temperature dan tekanan di dalam chamber mesin curing.

Distribusi Weibull biasanya digunakan untuk menyelesaikan masalah-masalah yang menyangkut lama waktu (umur) suatu objek yang mampu bertahan hingga akhirnya objek tersebut tidak berfungsi sebagaimana mestinya (kegagalan atau failure). Menurut ebelling, salah satu pola kerusakan komponen dengan laju failure yang meningkat seiring waktu penambahan waktu operasi komponen dikelompokkan pada kategori wear-out dan solusi upaya recovery kehandalan yang perlu dilakukan adalah menggunakan perawatan yang terencana [8].

Berikut adalah beberapa fungsi untuk menghitung distribusi Weibull.

$$
\begin{aligned}
& x i=\ln (x) \\
& y i=\ln (-\ln (1-F(x)) \\
& F(x i)=(n-0.5) / 11 \\
& \beta=\frac{n \sum x i y i-\left(\sum x i \sum y i\right)}{n \sum x_{i}^{2}-\left(\sum x i\right)^{2}} \\
& \alpha=\frac{\sum y i-\left(\beta \sum x i\right)}{n} \\
& \text { MTBF actual }=\frac{\sum x}{n} \\
& \text { MTBF estimasi }=\alpha * \operatorname{Exp}\left(\ln \left(1+\frac{1}{\beta}\right)\right.
\end{aligned}
$$


Perhitungan index of fit time dilakukan untuk menentukan distribusi kerusakan komponen yang nantinya akan digunakan untuk melakukan perhitungan mean time to failure (MTTF). Data nilai time to failure (TTF) diambil dari waktu perawatan yang telah dilakukan hingga terjadi kerusakan, dan selang waktu dari perbaikan hingga terjadi kerusakan kembali.

\section{HASIL}

Sesuai dengan fokus kajian pembaharuan jadwal PM menggunakan metoda distribusi Weibull untuk menganalisa dan memilah komponen dengan karakter kegagalannya akan semakin tinggi seiring waktu penggunaannya (atau nilai index $\beta>1$ ). Strategi perawatan PM diperuntukkan untuk jenis Kegagalan obyek dengan nilai index $\beta>1$. Terdapat dua komponen mesin curing dengan nilai index $\beta>1$ yaitu silinder press dan EPV (Electronic Propotional Valve).

\subsection{Index of fit time to failure (TTF) komponen selinder press.}

\subsubsection{Data histori perawatan komponen selinder press.}

Pada grafik 3.1 ditunjukkan data hasil penelusuran riwayat downtime mesin curing yang terdiri dari downtime terencana PM maupun downtime yang tidak terencana. Downtime terencana (PM) ditampilkan dengan garis berwarna merah dilaksanakan dengan selang waktu ruting setiap 180 hari. Downtime tidak terencana karena adanya mesin breakdown ditampilkan dengan warna biru. Downtime mesin curing dari bulan januari 2016 hingga januari 2019 terdiri dari 5 kali downtime PM terencana dan 19 kali downtime tidak terencana.

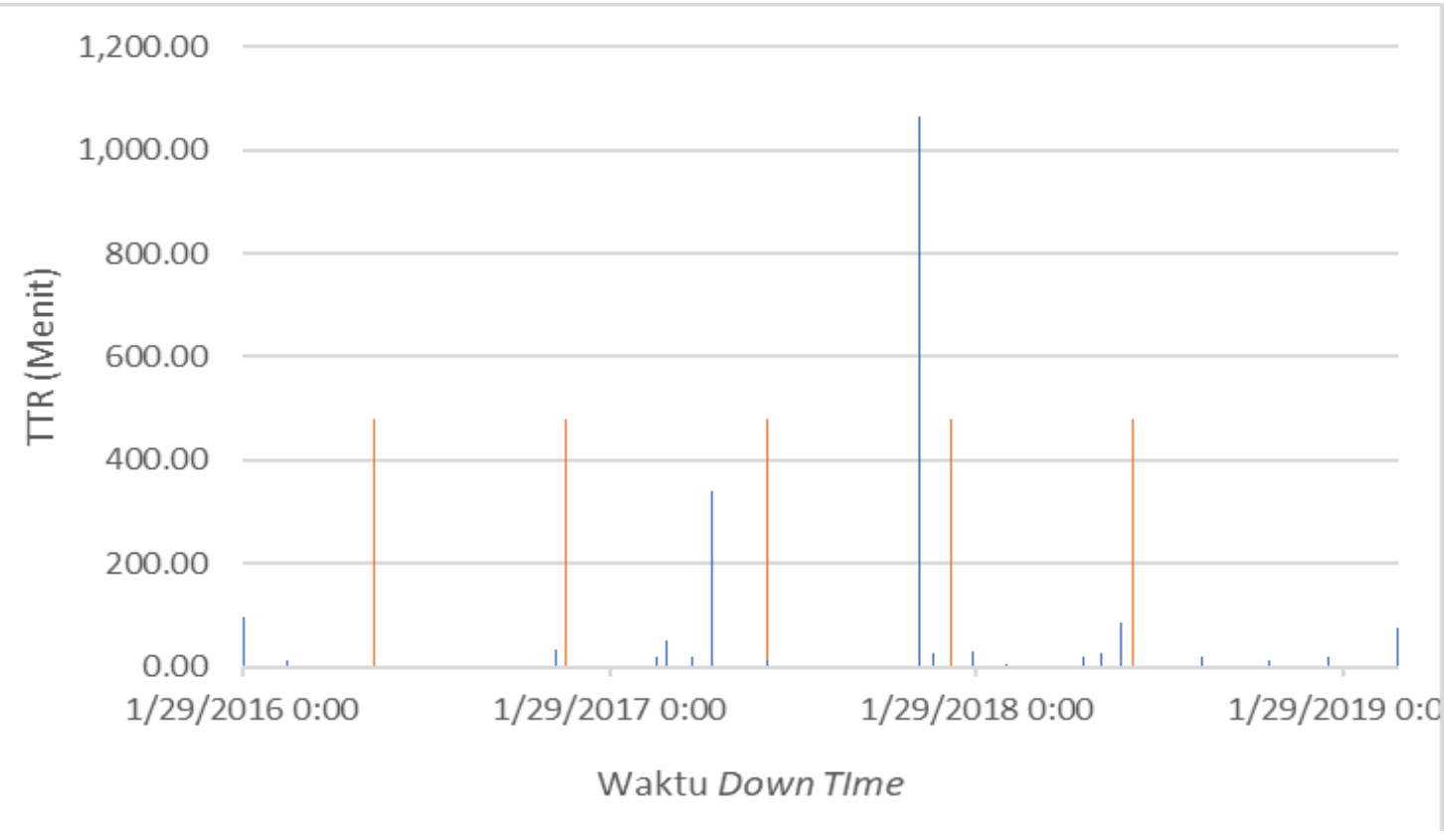

Gambar 2. Grafik downtime mesin curing

Total lamanya mesin berhenti (Time to Repair) untuk downtime tidak terencana karena adanya 19 kali mesin breakdown adalah 1.872 menit. Sehingga menggunaan persamaan 3 maka nilai Mean Time to Repair(MTTR)_nya adalah:

MTTR $=1.872 / 19=98,52$ menit. 
Total selang waktu antar kegagalan/kerusakan terjadi (Time to Failure) adalah 1182,63 hari, sehingga menggunakan persamaan 2 maka nilai Mean Time Between Failure (MTBF) _nya ialah:

MTBF $=1182,63 / 19=62,24$ hari.

\subsubsection{Nilai index of fit time TTF komponen silinder press}

Perhitungan index of fit TTR silinder press menggunakan data riwayat kegiatan perawatan (down time) yang melibatkan komponen selinder press. Pada dokumen detail kegiatan perawatan mesin curing menunjukkan bahwa komponen selinder press ternyata tidak termasuk dalam item obyek komponen yang diperbaiki pada kegiatan PM, sehingga data TTF komponen dihitung secara aktual hanya berdasarkan TTF antar kegiatan perawatan tidak terencana. Pada table 1. ditampilkan perhitungan index of fit TTR selinder press. $x$ adalah waktu antar terjadinya kerusakan (TTR) selinder press.

Tabel 1. Perhitungan index of fit TTR selinder press

\begin{tabular}{cccccc}
\hline $\mathbf{i}$ & $\mathbf{x}$ & sort $\mathbf{x}$ & $\mathbf{I n}(\mathbf{x})$ & $\mathbf{F}(\mathbf{x})$ & $\ln (-\operatorname{In}(\mathbf{1 - F}(\mathbf{x})))$ \\
\hline 1 & 412.313 & 17.840 & 2.881 & 0.045 & -3.068 \\
2 & 34.815 & 19.977 & 2.995 & 0.136 & -1.920 \\
3 & 19.977 & 20.476 & 3.019 & 0.227 & -1.355 \\
4 & 53.767 & 34.815 & 3.550 & 0.318 & -0.960 \\
5 & 153.889 & 53.767 & 3.985 & 0.409 & -0.642 \\
6 & 84.747 & 66.456 & 4.197 & 0.500 & -0.367 \\
7 & 77.205 & 77.205 & 4.346 & 0.591 & -0.112 \\
8 & 17.840 & 79.427 & 4.375 & 0.682 & 0.136 \\
9 & 20.476 & 84.747 & 4.440 & 0.773 & 0.393 \\
10 & 79.427 & 153.889 & 5.036 & 0.864 & 0.689 \\
11 & 66.456 & 412.313 & 6.022 & 0.955 & 1.129 \\
\hline
\end{tabular}

Pada gambar 3. Ditunjukkan grafik index of fit time selinder press. Distribusi nilai memiliki karakteristik yang cendrung naik, artinya kerusakan komponen selinder press akan semakin meningkat seiring waktu penggunaannya. Jenis karakteristik kerusakan komponen ini membutuhkan perlakukan teknik perawatan preventive maintenance. 
Usulan Pembaharuan jadwal Kegiatan Preventive Maintenance pada Mesin Curing PCR PT.XYZ Menggunakan Metoda Distribusi Weibull

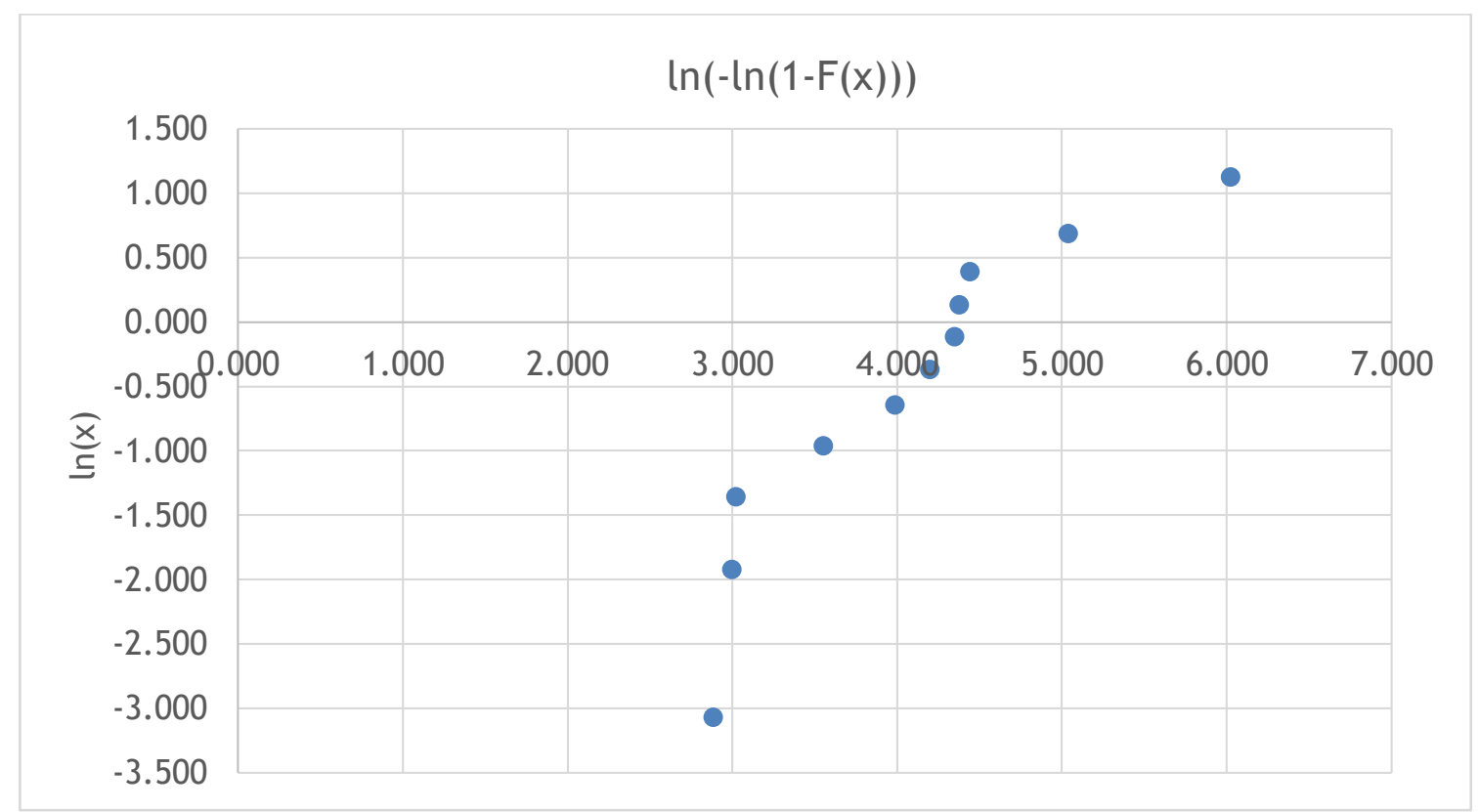

Gambar 3. Grafik index of fit time selinder press.

Sesuai persamaan (4), persamaan (5) dan persamaan (6) untuk perhitungan xi; yi; dan F(xi) maka parameter selinder press secara lengkap ditampilkan pada table 2.

Tabel 2. Perhitungan index of fit 2 selinder press

\begin{tabular}{ccccccc}
\hline $\mathbf{N}$ & $\mathbf{X i}$ & $\mathbf{F}(\mathbf{x i})$ & $\mathbf{Y i}$ & $\mathbf{\mathbf { x i } ^ { \mathbf { 2 } }}$ & $\mathbf{y i \mathbf { }}$ & $\mathbf{x i} \mathbf{y i}$ \\
\hline 1 & -3.07 & 0.05 & -3.07 & 9.41 & 88.58 & -28.87 \\
2 & -1.92 & 0.14 & -1.92 & 3.69 & 13.59 & -7.08 \\
3 & -1.36 & 0.23 & -1.36 & 1.84 & 3.38 & -2.49 \\
4 & -0.96 & 0.32 & -0.96 & 0.92 & 0.85 & -0.88 \\
5 & -0.64 & 0.41 & -0.64 & 0.41 & 0.17 & -0.27 \\
6 & -0.37 & 0.50 & -0.37 & 0.13 & 0.02 & -0.05 \\
7 & -0.11 & 0.59 & -0.11 & 0.01 & 0.00 & 0.00 \\
8 & 0.14 & 0.68 & 0.14 & 0.02 & 0.00 & 0.00 \\
9 & 0.39 & 0.77 & 0.39 & 0.16 & 0.02 & 0.06 \\
10 & 0.69 & 0.86 & 0.69 & 0.48 & 0.23 & 0.33 \\
11 & 1.13 & 0.96 & 1.13 & 1.27 & 1.62 & 1.44 \\
$\Sigma$ & -6.08 & 5.50 & -6.08 & 18.34 & 108.46 & -37.81 \\
\hline
\end{tabular}

Perhitungan MTBF aktual menggunakan persamaan (9), kemudian perhitungan nilai $\beta$ dan nilai a untuk mendapatkan nilai MTBF estimasi Weibull komponen selinder press menggunakan persamaan (7) dan (8).

$$
\begin{aligned}
& \beta=\frac{n \sum x i y i-\left(\sum x i \sum y i\right)}{n \sum x_{i}{ }^{2}-\left(\sum x i\right)^{2}}=1,188 \\
& \alpha=\frac{\sum y i-\left(\beta \sum x i\right)}{n} \quad=93,879
\end{aligned}
$$




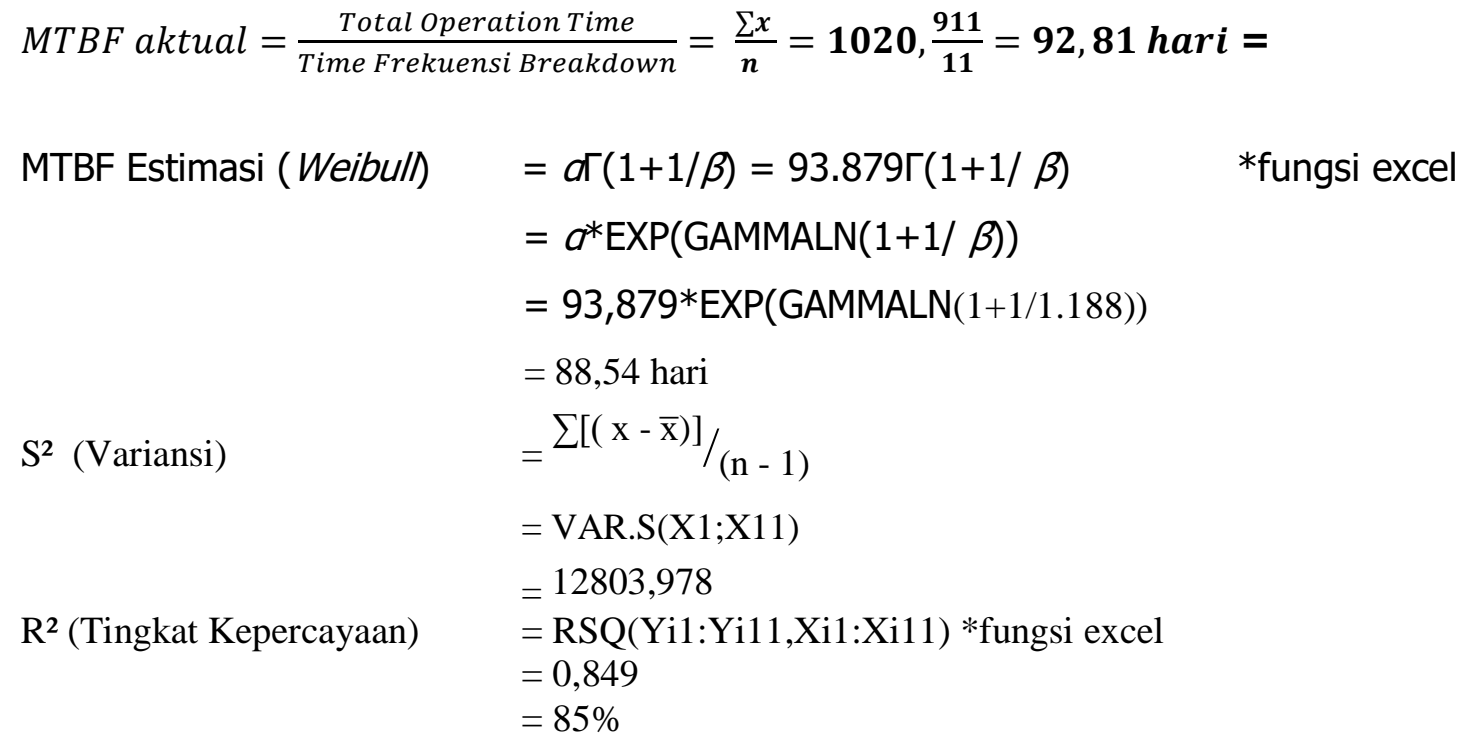

$\beta$ dan a merupakan koefisien weibull yang digunakan untuk menghitung MTBF weibull. $\beta>1$ menunjukkan bahwa karakter kerusakan komponen terjadi meningkat seiring dengan bertambahnya waktu penggunaan komponen, maka direkomendasikan untuk dilakukan perawatan berkala atau preventive maintenance. MTBF aktual adalah perhitungan MTBF dengan menghitung rata-rata waktu kerusakan terjadi seperti perhitungan di atas dengan hasil 92,81 hari. MTBF estimasi Weibull yang dihitung menggunakan $\beta$ dan a merupakan interval perawatan dari silinder press yang direkomendasikan yaitu setiap 88,54 hari. 
Usulan Pembaharuan jadwal Kegiatan Preventive Maintenance pada Mesin Curing PCR PT.XYZ Menggunakan Metoda Distribusi Weibull

\subsubsection{Kemampuan survivability komponen selinder press}

Perhitungan survivalbility menggunakan probabilitas dengan tools add-on probabilitas Microsoft Excel. [9]

Dengan fungsi probabilitas $=1$-WEIBULL( $\$$ "Waktu (Hari)", $\beta, a$,TRUE)

Grafik hasil perhitungan survivalbility sebagai berikut:

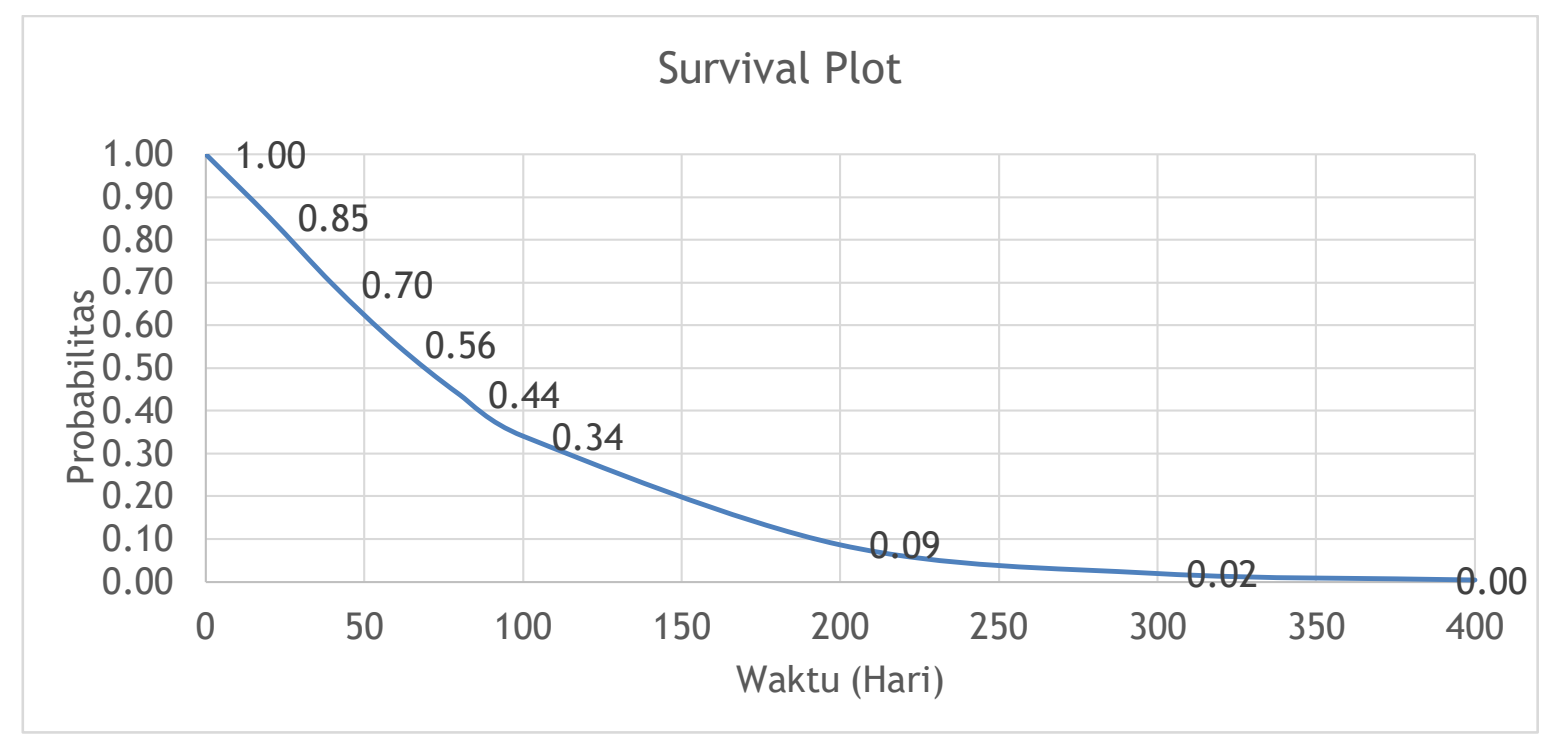

Gambar 4. Grafik survavibility selinder press

Pada tabel 3. ditunjukkan presentasi probabilitas komponen silinder press untuk tidak rusak setelah melalui waktu penggunaan. Kemungkinan selinder press masih berfungsi dengan baik setelah 88,54 hari adalah $39 \%$.

Untuk mengetahui persentase kemungkinan berapa hari komponen dapat bertahan setelah perbaikan dapat ditentukan dengan:

Tabel 3. Prosentasi probabilitas survavibilitas selinder press

\begin{tabular}{cc}
\hline $\mathbf{p}$ & Waktu (Hari) \\
\hline $1 \%$ & 338.75 \\
$10 \%$ & 189.20 \\
$20 \%$ & 140.02 \\
$30 \%$ & 109.72 \\
$39 \%$ & 88.54 \\
$40 \%$ & 87.22 \\
$50 \%$ & 68.99 \\
$60 \%$ & 53.38 \\
$70 \%$ & 39.47 \\
$80 \%$ & 26.61 \\
$90 \%$ & 14.17 \\
$95 \%$ & 7.74 \\
$99 \%$ & 1.97 \\
\hline
\end{tabular}




\subsubsection{Data histori perawatan komponen EPV mesin curing}

hasil penelusuran riwayat downtime mesin curing dari bulan januari 2016 hingga januari 2019 terdiri dari 5 kali downtime PM terencana dan 6 kali downtime tidak terencana karena adanya kerusakan pada komponen EPV.

\subsubsection{Perhitungan index of fit Time to Failure komponen EPV}

Tabel 4. Perhitungan Index of fit TTF EPV

\begin{tabular}{cccccc}
\hline $\mathbf{i}$ & $\mathbf{x}$ & $\mathbf{s o r t} \mathbf{x}$ & $\mathbf{I n}(\mathbf{x})$ & $\mathbf{F}(\mathbf{x})$ & $\ln (-\ln (\mathbf{1}-\mathbf{F}(\mathbf{x})))$ \\
\hline 1 & 266.8064352 & 39.898 & 3.686 & 0.083 & -2.442 \\
2 & 100.8818634 & 100.881863 & 4.614 & 0.250 & -1.246 \\
3 & 165.3246759 & 165.324676 & 5.108 & 0.417 & -0.618 \\
4 & 39.89815972 & 266.806435 & 5.587 & 0.583 & -0.133 \\
5 & 353.2620833 & 353.262083 & 5.867 & 0.750 & 0.327 \\
6 & 388.25 & 388.25 & 5.962 & 0.917 & 0.910 \\
\hline
\end{tabular}

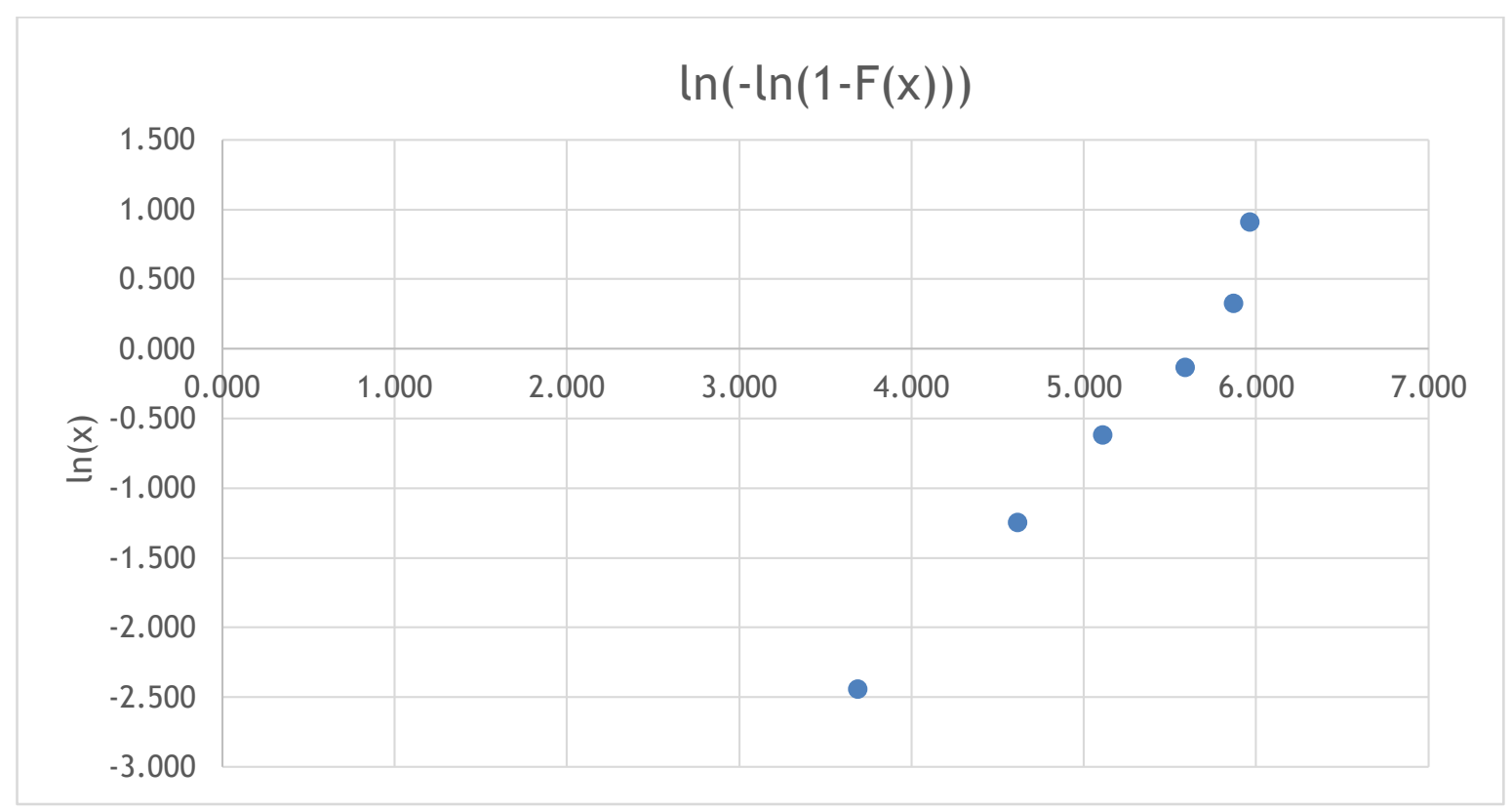

Gambar 5. Grafik index of fit TTF EPV

Pada Gambar 5. ditunjukkan grafik index of fit TTF komponen EPPV, dimana karakteristiknya menunjukkan semakin meningkat seiring waktu sehingga perlu dilakukan perlakuan teknik perawatan PM.

Sesuai persamaan (4), persamaan (5) dan persamaan (6) untuk perhitungan xi; yi; dan F(xi) maka parameter EPV secara lengkap ditampilkan pada table 5. 
Tabel 5. Perhitungan index of fit TTF EPV

\begin{tabular}{ccccccc}
\hline $\mathbf{n}$ & $\mathbf{x i}$ & $\mathbf{F}(\mathbf{x i})$ & $\mathbf{y i}$ & $\mathbf{x i}^{\mathbf{2}}$ & $\mathbf{y i \mathbf { }}$ & $\mathbf{x i} . \mathbf{y i}$ \\
\hline 1 & 3.686 & 0.083 & -2.442 & 13.589 & 5.962 & -9.001 \\
2 & 4.614 & 0.250 & -1.246 & 21.289 & 1.552 & -5.749 \\
3 & 5.108 & 0.417 & -0.618 & 26.091 & 0.382 & -3.157 \\
4 & 5.587 & 0.583 & -0.133 & 31.209 & 0.018 & -0.743 \\
5 & 5.867 & 0.750 & 0.327 & 34.424 & 0.107 & 1.916 \\
6 & 5.962 & 0.917 & 0.910 & 35.541 & 0.829 & 5.427 \\
$\Sigma$ & 30.82 & 3.00 & -3.20 & 162.14 & 8.85 & -11.31 \\
\hline
\end{tabular}

Perhitungan MTBF actual menggunakan persamaan (9), kemudian perhitungan nilai $\beta$ dan nilai a untuk mendapatkan nilai MTBF estimasi Weibull komponen EPV menggunakan persamaan (7) dan (8).

$$
\begin{aligned}
& \beta=\frac{n \sum x i y i-\left(\sum x i \sum y i\right)}{n \sum x_{i}^{2}-\left(\sum x i\right)^{2}}=1,355 \\
& \alpha=\frac{\sum y i-\left(\beta \sum x i\right)}{n} \quad=252,4 \\
& \text { MTBF aktual }=\frac{\text { Total Operation Time }}{\text { Time Frekuensi Breakdown }}=\frac{\sum x}{n}=1341,42 / 6=219,07 \text { hari } \\
& \text { MTBF Estimasi (Weibul) } \quad=a \Gamma(1+1 / \beta)=93.879 \Gamma(1+1 / \beta) \quad \text { *fungsi excel } \\
& =a^{*} \operatorname{EXP}(\operatorname{GAMMALN}(1+1 / \beta)) \\
& =252,4 * \operatorname{EXP}(\operatorname{GAMMALN}(1+1 / 1.188)) \\
& =231,29 \text { hari } \\
& \mathrm{S}^{2} \text { (Variansi) } \quad=\sum[(\mathrm{x}-\overline{\mathrm{x}})] /(\mathrm{n}-1) \\
& =\mathrm{VAR} \cdot \mathrm{S}(\mathrm{X} 1 ; \mathrm{X} 11) \\
& =19573,55 \\
& \mathrm{R}^{2} \text { (Tingkat Kepercayaan) } \quad=\mathrm{RSQ}(\text { Yi1:Yi11,Xi1:Xi11) *fungsi excel } \\
& =0,975
\end{aligned}
$$

$\beta$ dan a merupakan koefisien weibull yang digunakan untuk menghitung MTBF. $\beta>1$ menunjukkan bahwa karakter kerusakan komponen terjadi meningkat seiring dengan bertambahnya waktu penggunaan komponen, maka direkomendasikan untuk dilakukan perawatan berkala atau preventive maintenance. MTBF aktual adalah perhitungan MTBF dengan menghitung rata-rata waktu kerusakan terjadi seperti perhitungan di atas dengan hasil 219,07 hari. MTBF estimasi Weibull yang dihitung menggunakan $\beta$ dan a merupakan interval perawatan dari silinder press yang direkomendasikan yaitu setiap 231,29 hari.

\subsubsection{Perhitungan survivability komponen EPV}

Perhitungan survivalbility menggunakan probabilitas dengan tools add-on probabilitas Microsoft Excel [6]. Formula fungsi probabilitas yaitu 1-WEIBULL(\$"Waktu (Hari)", $\beta$, a ,TRUE). Hasil perhitungan survivalbility ditunjukkan pada grafik gambar 6 . sebagai berikut: 


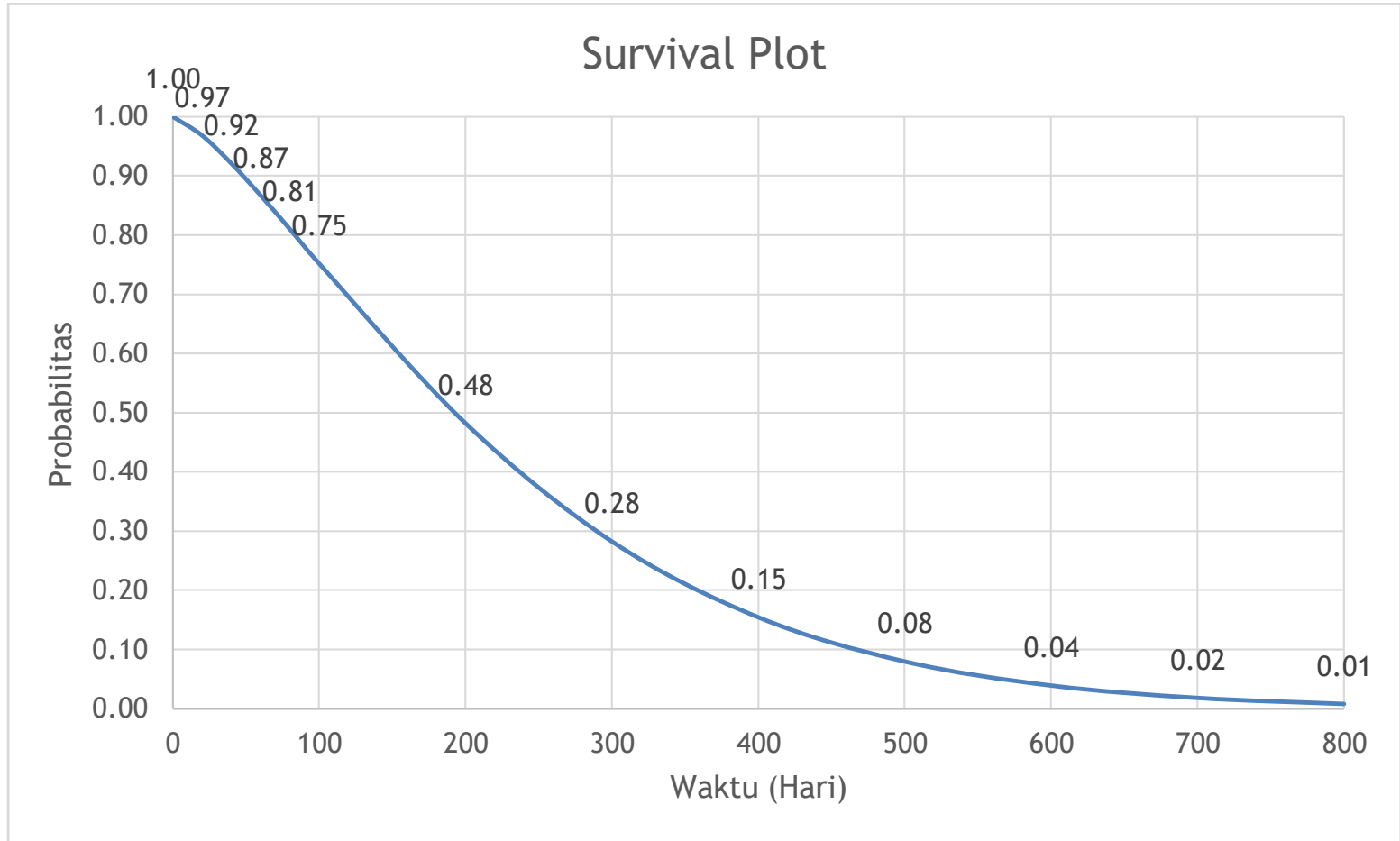

Gambar 6. Grafik survavibility EPV

Pada tabel 6. ditunjukkan presentasi probabilitas komponen EPV untuk tidak rusak setelah melalui waktu penggunaan. Kemungkinan EPV masih berfungsi dengan baik setelah 231,29 hari adalah $49 \%$.

Untuk mengetahui persentase kemungkinan berapa hari komponen dapat bertahan setelah perbaikan dapat ditentukan dengan:

Tabel 6. Prosentasi probabilitas survavibility selinder press

\begin{tabular}{cc}
\hline $\mathbf{p}$ & Waktu (Hari) \\
\hline $1 \%$ & 779.06 \\
$10 \%$ & 467.10 \\
$20 \%$ & 358.61 \\
$30 \%$ & 289.46 \\
$40 \%$ & 236.63 \\
$41 \%$ & 231.29 \\
$50 \%$ & 192.58 \\
$60 \%$ & 153.74 \\
$70 \%$ & 117.94 \\
$80 \%$ & 83.43 \\
$90 \%$ & 47.95 \\
$95 \%$ & 28.19 \\
$99 \%$ & 8.47 \\
\hline
\end{tabular}


Usulan Pembaharuan jadwal Kegiatan Preventive Maintenance pada Mesin Curing PCR PT.XYZ Menggunakan Metoda Distribusi Weibull

\section{KESIMPULAN DAN RENCANA PENELITIAN BERIKUTNYA}

Dari penelitian yang telah dilakukan, jadwal PM mesin curing perlu diperbaharui. Beberapa hal yang harus diperhatikan pada pembaharuan jadwal adalah:

- Penggunaan metoda distribusi Weibull untuk mendapatkan komponen penyebab mesin sering breakdown dengan nilai $\beta>1$ atau berkarakteristik laju kegagalan yang membutuhkan perlakuan perawatan preventive maintenance.

- Terdapat dua komponen yang perlu dipertimbangkan dalam lingkup item komponen dengan perawatan PM, yaitu selinder press dan EPV (Electronic Propotional Valve).

- Nilai index of time to failure yang menjadi nilai acuan expected lifetime atau selang waktu PM dari komponen selinder press dan EPV adalah 89 hari dan 231 hari.

- Usulan pembaharuan jadwal PM mesin agar mempertimbangkan penambahan kegiatan PM baru yang mengakomodir nilai durasi expected lifetime dari komponen-komponen penyebab mesin breakdown, sehingga tidak terjadi kegiatan perawatan yang tidak terencana dan menyebabkan line produksi berhenti.

Rencana penelitian berikutnya adalah penelusuran komponen kritis setiap peralatan produksi pada line produksi pembuatan ban untuk usulan pembaharuan jadwal PM secara keseluruhan.

\section{REFERENSI}

[1] F.G. Badia, dkk,"Optimal Inspection and Preventive Maintenance of Units with Reavealed and Unrevealed Failures", Reliability Engineering and system Safety, 78, 157-163, 2002.

[2] V. Mijailovic, "Probabilistic Method for Planning of Maintenance Activities of substain Component", electric Power system Research, 64, 53-58, 2003.

[3] H.P. Garg. Industrial Maintenance. New Delhi, India; S. Chand \& Company LTD. 2002.

[4] S. Borris. Handbook on the Total Productive Maintenance. New York; McGraw Hill, 2006.

[5] A. Charles, dkk, "Optimization of Preventive Maintenance strategies in a multipurpose batch plant: Application to Semiconductor Manufacturing", Computer and chemical engineering, 27, 449-467, 2003.

[6] I. Sodikin, "Penentuan Perawatan Preventive Komponen elektrik dan komponen Mekanik yang optimal pada mesin excapator seri PC 200-6 dengan Pendekatan Model Jardine", Jurnal Teknologi, vol.1 Nomor 2, 2008.

[7] D.S. Dhamayanti, dkk, "Usulan Preventive Maintenance pada Mesin Komori LS440 dengan Menggunakan Metode Reliability Centered Maintenance (RCM II) dan Risk Base Maintenance (RBM) di PT ABC", Jurnal Rekayasa Sistem \& Industri, Vol. 3, Nomor 2, 2016.

[8] C. Ebelling. Reliability \& Maintainability Engineering. New York; McGraw Hill, 1997.

[9] Charles Zaiontz, The Real Statistics Resource Pack by Charles Zaiontz. 